University for Business and Technology in Kosovo

UBT Knowledge Center

Oct 27th, 10:45 AM - 12:15 PM

\title{
Electronic Media written in albanian a mean of appropriately informing the audience, respectively Media of Kosovo
}

\author{
Ferid Selimi \\ University for Business and Technology, ferid.selimi@ubt-uni.net
}

Follow this and additional works at: https://knowledgecenter.ubt-uni.net/conference

Part of the Journalism Studies Commons

\section{Recommended Citation}

Selimi, Ferid, "Electronic Media written in albanian a mean of appropriately informing the audience, respectively Media of Kosovo" (2018). UBT International Conference. 239.

https://knowledgecenter.ubt-uni.net/conference/2018/all-events/239

This Event is brought to you for free and open access by the Publication and Journals at UBT Knowledge Center. It has been accepted for inclusion in UBT International Conference by an authorized administrator of UBT Knowledge Center. For more information, please contact knowledge.center@ubt-uni.net. 


\title{
Electronic Media written in albanian a mean of appropriately informing the audience, respectively Media of Kosovo
}

\author{
Ferid Selimi \\ UBT - Institucion i Arsimit të lartë, Lagjja kalabria, 10000 p.n., Prishtinë, Kosovë \\ ferid.selimi@ubt-uni.net
}

\begin{abstract}
Due to the fact that media in Kosovo is in itself an industry which consistently provides information and thereafter transmits it to the public, it's worth emphasizing that its activity is regulated by law and the respective legal acts that are concerned with Media. Consequently, lack of respecting those rules that derive from normative legal acts, Media comprises in itself a precedent of disrespecting legal acts. According to Media scholars, the authenticity is the underlying aspect of evoking trustworthiness, which is enhanced by consciousness that is the gist of information. The course of technological developments has brought above changes as far as speed of conveying news, techniques of spreading news are concerned. Moreover there exists even a philosophical theory that derives from the way how information is structured. Based on a research carried out in Kosovo with respondents from a wide range of ages 18-65 of both genders, part of Media are also considered even social media. According to a rapport of Freedom House Media is adversarily affected in it's independence and this has caused Kosovo to be ranked among states which are considered partly free. In the list compiled by this institution Kosovo is ranked in 78 position.
\end{abstract}

Key words; Trustworthiness, information, Kosovo, Media, respondents. 


\section{Introduction}

Due to the fact that the media represents in itself an information provider industry which activity is regulated by law, it implies that they are or should at least be in the function of performing the obligation of their primary public information in accordance with the legal acts regulating the media. Thanks to technological developments, citizens have the opportunity of being informed at any time. Every citizen is given the chance to browse a large number of newsletters, magazines, radio, television, social media and social networks through the cell phone and find information in different fields, with just one internet access, and with a few clicks on different pages. However, it's worth raising the question if are they well-informed or not? What information does it really take? Is it true that media is a means of informing and broadcasting news or does it represent the broad scope of multifaceted news itself? It's worth bearing in mind the irrelevance of the rules that derive from the normative legal acts. Obviously, it is in disregard with the media principles to provide news on daily basis which are irrelevant with legal acts. Undoubtedly, this comes as a result of acquiring information that the media receives from citizens and informing citizens of the information they receive from citizens. Consequently, citizens inform through various social networks, and the media receive such information as they can find it and without verifying them at all before the citizens, respectively before their followers, without breaking their heads if they violate any legal and ethical act which regulates fair information, including: Law on defamation and insult; Law on the Protection of Journalists' Resources; journalistic codex and ethics in journalism. Nevertheless media seems to lose the trust readers demand from them. This paper elaborates and deeply scrutinizes the findings of a research on electronic media in Kosovo, concerned with their function in publishing information provided by citizens to inform citizens. As far as this principle, the Law Against Defamation and Insult in Kosovo has been consulted, the literature that mentions this issue, and the method of interview, survey and survey was used. Based on the Law Against Defamation and Insult, in Kosovo "no one will be liable for defamation and insult to a statement of a matter of public interest if they prove to be reasonable in all circumstances for a person in their position of spread the material with good intentions. Being aware of the importance of freedom of expression, regarding matters of public interest so that it may result in timely information on such matters. " This means that the degree of nonliability for publishing a news item that could be offensive but which is of common interest is stipulated by (Law No. 02 / L-65 Civil Law Against Defamation and Insult). Indeed, based on the number of printed newspapers for many years in Kosovo, the quantity of printed copies and the increase in online newspapers, it is rightly raised a hypothesis that because of the speed of the news spread, enough information sources, the news published in print electronic media in Kosovo has lost credibility. Based on the findings, the conclusions on which this hypothesis relies on 


\section{The underlying objective of this research}

The underlying purpose of this study is to profoundly scrutinize the core function of information that is carried out by means of electronic print media. The main focus of this study is to analyze technology and the Internet have influenced on reducing the reliability of information, namely the news published in Albanian electronic media in Kosovo. However it is worth raising this question; "How is the electronic media affecting the credibility, trustfulness of news? Does social media bear trustworthiness in itself or it distorts information?

\section{Research Methodology}

Indeed the drafting of this papers is primarily based on the following scientific methods; the interview method, the survey method. Through the interview method, there were depicted accurate data regarding the media development along a certain period of time and as a matter of a fact there were interviewed numerous senior journalists in Kosovo. Through the survey method, data on the credibility of print media in Kosovo were provided. While the survey method is used to analyze the quality of news in online newsletters. Data which is depicted in is processed and sorted by relevance, placing it in the right place. First and foremost, in November 2017 , there was initiated a questionnaire, which was thereafter launched electronically to Kosovo Albanian citizens. Furthermore, answers which were received have been elaborated within two weeks. During the third week the material was processed and meticulously arranged in relevance with the required standards. Lastly, within the fourth week, there was compiled and structured the section of this paper. In the first week of July 2018, there was carried out a questionnaire regarding the credibility of electronic media written in Albanian in Kosovo was made. This questionnaire was also sent electronically to students, scholars, journalists and citizens of different backgrounds. The scientific work has been arranged and accurately processed during the third week of July.

\section{Research Samples}

Samples of this paper were obtained through online newspapers in Kosovo: voice, "gazetaexpress.com", newspaper "koha.net". insajderi.com; indeksonline; Freedom House Report of "Reporters Without Borders". The instruments used were Kosovo Albanian citizens aged 18-65 years, users of one of the social networks. In 2017, 350 respondents were interviewed, while in 2018500 respondents from all regions of the Republic of Kosovo were interviewed.

\section{Albanian-language electronic media in Kosovo and the purpose of public information}

In addition to print and visual media, in Kosovo there are also electronic print media, which are considered attractive to readers for several reasons, as Hollander also states (Hollander et al., 2011; Van Cauwenberge et al., 2015). In Kosovo, there are enough legal provisions to ensure that written electronic media are responsible for their 
actions. However, the state has not drafted nor approved the regulation of broadcasters type in written electronic media, as is the case with most developed countries. Nevertheless in industrialized countries, journalists and scholars of journalism have been consistently striving for developing of the print media by generating new ideas in the early twentieth century. Lippmman thought that the good presentation of the news should be made through great scientific values. (Kovach, 2009) However, over the years, the original and most sophisticated interpretation of objectivity is completely distorted, says Bill Kovach. Many of the journalists had never understood this paradigm. They had labeled the concept of objectivity as false. It should be noted that it was not just Lippmman who sought higher professionalism in journalism. Before him was Joseph Pulitzer, who, to assist in the professionalization of journalism, had created the Graduate School of Journalism at Columbia University. (Kovach, 2009). Hollander and his associates point out that switching from printed newsletters to online is done for several reasons, and two of them are the lowest cost and delivery speed. (Hollander et al., 2011; Van Cauwenberge et al., 2015). Without getting the cost of these media at all, news distribution is lucid and straightforward which avoids vulnerability and costs of distributing copies of paper (Kanter, 2008). That the truth of a news has nothing to do with the truthfulness of the news, this has been proved several times. Recently, various events have been published, which were initially published as true news, and thereafter it was proven that it did not happen as reported despite of the fact that news may have even been received by reliable officials . (Recall the US Secretary of State's statement at the 1963 Press Conference after visiting US troops in Vietnam, a news story that was published in some media and then its authenticity in 1971). (Kovach, 2009) Or when the Boston Marathon bombardment was covered in 2013, the New York Post published a picture on her first page of two men claiming to be the suspects that federal investigators were looking at at that time. The men turned out to be innocent. The paper apologized for the mistake, but the men later filed for defamation (Wemple, 2014). Soren Kierkegaard at Three Building Teaching has emphasized that things are not seen or understood equally. According to him, not everyone looks at the same thing. (Hong, 1843) Therefore, not for all truth is considered true and verity truthful. Ganimet Klaiqi, a longtime journalist of the Koha Ditore daily and former UBT lecturer, compared the journalism of the seventies and eighties of the twentieth century and the journalism that is being made today, states: "Nowadays, it's worth pointing out that the spectre of journalism, which has been awfully distorted, this hasn't come as a result of inaccurate textual structure, but owing to the fact that the text has been substantially altered. " Actually, according to Klaić, textual journalism does not languish in order, because the texts have good logic and are easily understood. "Real journalism doesn't rely on the distortion of information, but in leaving them inadequate, giving inaccurate information, asking for clicks, etc.". underlines Klaiqi. (February 14, 2017) The vast majority of the information comes from a new perspective, says Stephan Russ-Mohl, which would limit our attention. Undoubtedly, their main purpose is to inform the public with the newest ones that take place in the country, the region and the world, but not giving away information that would overburden us so much as to distract our attention. According to the report "Freedom Haus" of "Reporters Without Borders" and Media Independence in Kosovo, it was concluded that media in Kosovo, is malfunctioning, affected by direct 
and indirect interventions regarding politics, financial pressure, as well as powerful entrepreneurs. Nowadays, it is an undeniable truth that journalists who criticize Kosovo authorities are frequently being accused as "traitors" or "Serbs sympathizers", and to make the matter worse are even blamed of violating the constitution.

\subsection{Information and dissemination}

Durin the last decade, the media industry in Kosovo has also experienced a significant structural change. In course of the 21 st century, there was witnessed a a new era of security and information dissemination was launched, merging one to three. Writing, View, and Voice. Relationships between truth, news truth, and communication technology have an undeniable impact on how media works. Thus increasing the number of printed electronic media and increasing competition instead of increasing the quality and reliability of news published by these media are all the more unreliable. News is created not news. They are unkempt and puzzled to the reader. This is due to a regulatory gap regarding the oversight of electronic print media. Both the Independent Media Commission (IMC) and the Press Council of Kosovo (ICMM) are withdrawn from their moral responsibility for protecting the rights of individuals from the harmful content of the print media. According to the EC Progress Report, in Kosovo the number of internet users has reached almost $76 \%$, which is a $2 \%$ increase over the last two years. (see: European Commission, Progress Report for Kosovo in 2016) Increasing the number of Internet users and the boost in the number of print media are unlikely to have affected both the speed of the news spread and the the plurality of their publication. These are the two underlying factors have made the information accessible for by every citizen, whether or not journalist, writer, publisher or publisher. Whereas on the other hand, written electronic media have enabled citizens to be involved in writing and spreading news, increasing the number of published news, increasing the number of writers, lifting taboos that only the journalist informs, on the other hand has influenced the dissemination news from unreliable sources, and with it, has jeopardized the credibility of the content and the quality of the writings in these media. Bearing in mind that in Kosovo, freedom of expression is a constitutional right, defined in accordance with the general principles of the United Nations (UN) and the European Convention for the Protection of Human Rights, written electronic media that are established and operating in Kosovo, increasingly are becoming a threat to use for defamation purposes or to offend others that are in the public view of the public. Since this type of media is legally largely unregulated, the responsibility of the respective institutions and their integrity is low. Although the national legislature is in favor of freedom of expression and the media, when it comes to regulating written electronic media, the law does not set out clear instructions or institutional responsibilities. Therefore, in order to regulate the media in Kosovo, there is a need to amend certain provisions and rules of legislation in order to require accountability by the Independent Media Commission (IMC) to oversee these media. Because in the absence of sanctioning mechanisms for bearing accountability, the behavior of the print media is increasingly becoming a worrisome issue. This is quite concerning because, there is no specific media law, (there is a law regulating the protection of sources of information - Law No. 04 / L-137). Therefore, by using this legal gap, recently written print media in Kosovo have gained a 
significant popularity at the expense of traditional media, as these provide space for freedom of expression, allowing individuals to become creators of content, and by enabling them to be news writers. Consequently, while the freedom of expression is not properly controlled, the print media utilizes their space for publishing various news, often with information from suspicious sources, but which makes them gain excessive power and build on traditional media printed. The technological developments have brought above a rapid change as far as the distribution of news, means of journalistic writtings are concerned.

Obviously, there have been carried out numerous steps to improve the theory as well as philosophy and multifaceted theoretical part, to foster an unbiased journalism both in written and oral form.

\subsection{Findings in the framework of this research}

As far as findings are concerned the research, this research has taken place in November 2017 with 350 respondents aged 19-35 years and the other in July 2018 with 500 respondents aged $19-65$, in Kosovo $70 \%$ of respondents think that the media are all they are aware of. Indeed, this implies that the media are not only newspapers, magazines, radios, televisions, but also various social networks through which the vast majority of citizens exchange different information. Social networks are ranked at the third place concerning the accuracy and importance of information. $8 \%$ of respondents think that social networks are the media. Consequently, this means that information which is taken and delivered faster through social networks. The newspapers that have dropped the number of books and readability take the last place, and is in line with the number of copies sold. The information space has enabled citizens not only to be informed, but also to provide their individual opinions and point of views. Whereas as McLaugh emphasizes and highlights world seems small by utilizing the whole range of means of information but at the same time, to soften the quality of information. Undoubtedly this can be witnessed by the outcomes of the Information and Communication Technology Use Survey 2017, made by the Kosovo Agency of Statistics, where it was pointed out that $88.8 \%$ of households had access to internet at home, from any type of device. Analyzing the Answers to the Survey Question: What is considered as media information necessarily creates the impression that even though newspapers as the first media gathering, publishing and disseminating information have fallen far below. Due to the fact only $4 \%$ of respondents consider the media. Meanwhile, during the seventies of the twentieth century until the end of the eighties, newspapers were the ones that carried all the responsibility of disseminating news and informing the citizens. Nevertheless it's worth bearing in mind and recalling that in Kosovo, Albanian news broadcast via television started in 1975. (see more: Selimi, Ferid, Public Broadcaster 2016) Figure 1 shows the findings of what are considered media. From the respondents' answers, nothing is left to portals or television. However, a discrepancy in the multiplicity of responses can be seen immediately below. In addition, $70 \%$ of respondents think that everything that is being informed is the media, while for the radio only $1 \%$ think it is the media, although most of them hear the radio. Taking into account the findings of the paper, there is witnessed a lack unprofessionalism and a lack of ethics in these 
media. Trying to survive and increase their benefits, they have difficulty in maintaining the standards of journalistic ethics.

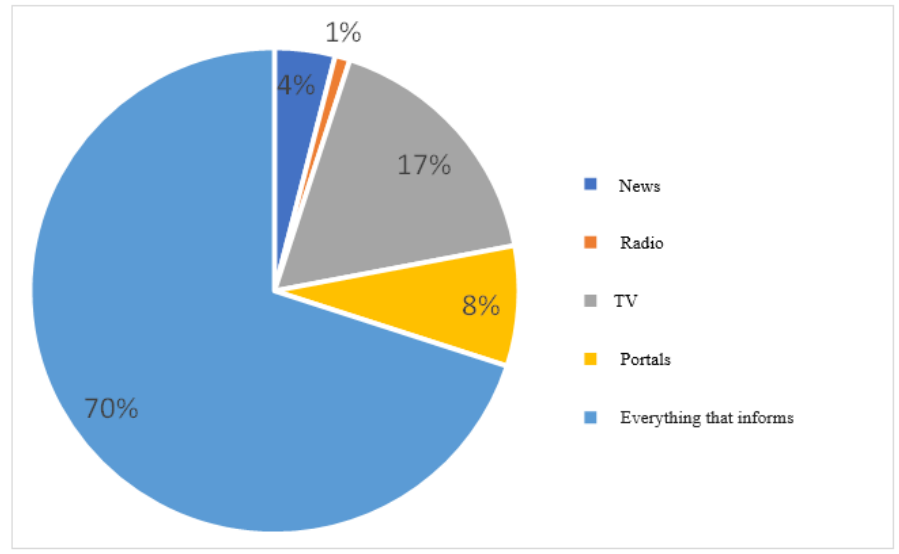

Fig. 1. Presentation of what media information is considered

As it is shown in Figure 1, 70\% of respondents consider Media Information to be all that informs. $17 \%$ think TV as media, $8 \%$ of respondents. Media is also comprised of social networks like Facebook, Instagram, Twiter. etc ... followed by $4 \%$ newspapers, while radio remains the last with $1 \%$ of respondents.

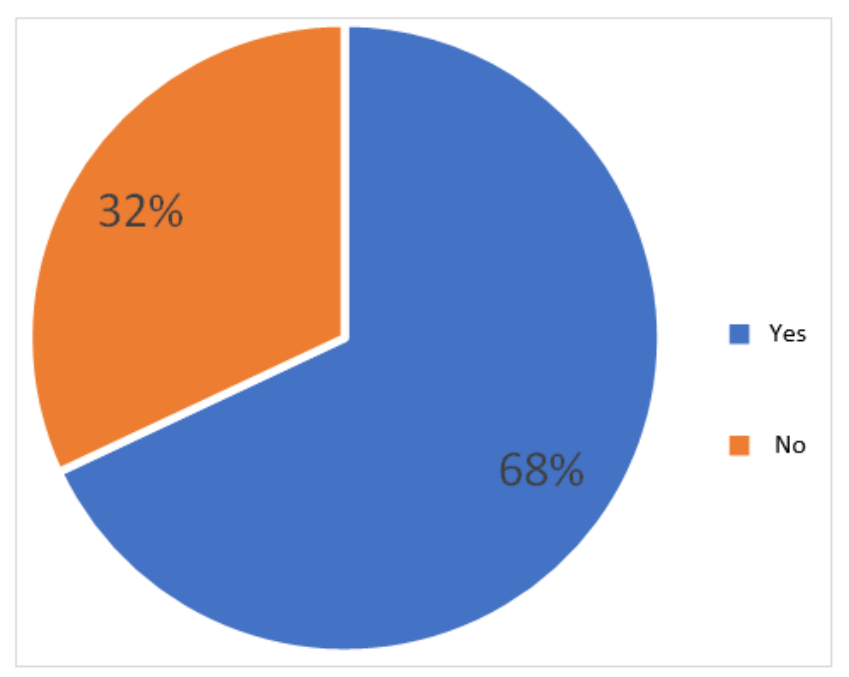

Fig. 2. Presentation with media figures 
This survey was carried out in 2017 where participated 350 Kosovar respondents of different ages, the results show that the reason for the news in a written electronic media is the quality of the news, leading by $46.8 \%$; followed by curiosity by $40.9 \%$. and the latest news coverage by $15.1 \%$;

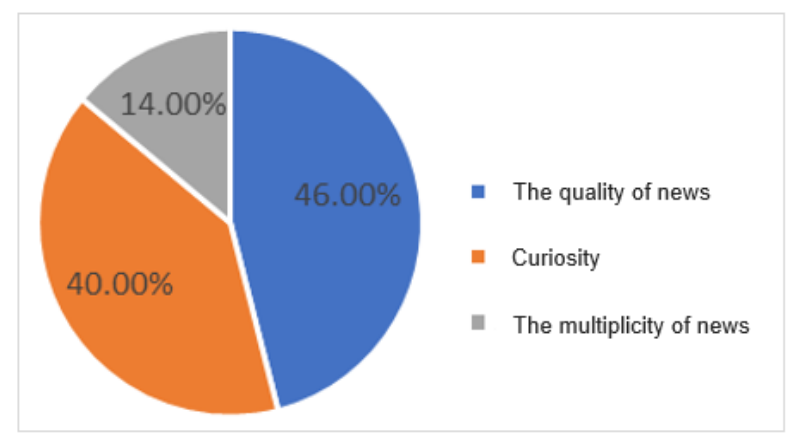

Fig. 3. The reasons which foster and increase the viewership of electronic media in Kosovo, regarding the objectivity and credibility of newspapers published in electronic print media. Due to the fact $21 \%$ of them say the news is objective, while $37 \%$ believe it, and $42 \%$ partially trust media.

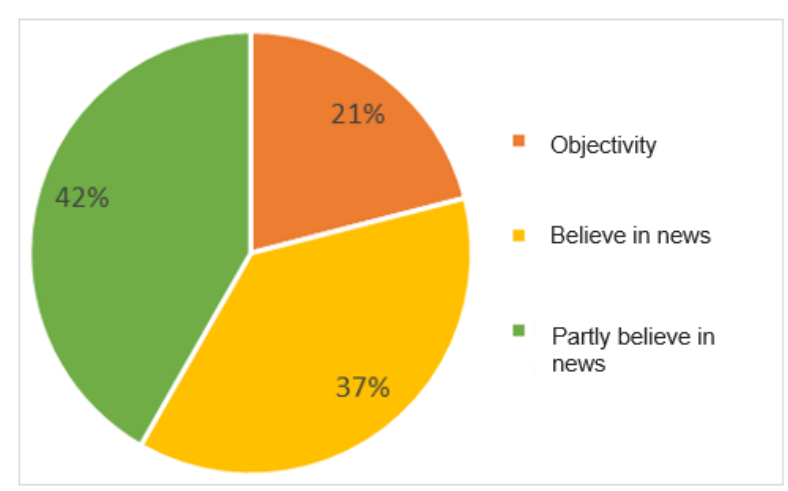

Fig. 4. Reliability of electronic media in Kosovo

As far as the feedback of respondents is concerned there is witnessed a dissatisfaction both in the objectivity and trustworthiness regarding the published news. 


\section{Conclusions}

Due to the fact that there has been perceived a strong tendency towards media convergence, as well as the possibility of simultaneously disseminating information through many channels, has brought forth adverse effects by made the process of change impossible to surpass even the print media in Kosovo. Based on freedom of expression, which is a constitutional right, defined in accordance with the general principles of the United Nations (UN) and the European Convention for the Protection of Human Rights, which implies that this freedom of expression can be exercised. Nevertheless not in such a way as to violate the rights of the other person nor to become a threat and to be used for defamation purposes or to offend them. Therefore, based on this principle, electronic media are subject to this Article of this Convention. The responsibility of expressing defamation instead of truth falls on the author and the media that issues it, even though the law has not yet defined the rules for written electronic media. Meanwhile IMC functions as a state regulatory body, it is legally responsible only for broadcast media. The PCC functions as a selfregulating body and has the right to promote freedom of expression without bearing any legal authority. Due to the fact that technology is being consistently being developed the news stifles the news for hundreds of seconds, the truth and truthfulness of the news in print media in Kosovo is still far from the standard of fair and accurate information. Public members have become writers, compilers, editors, and news publishers. Which means, those who used to consume the news now produce and distribute it in various forms and with various means, mainly via the internet. Citizens receive free of charge information and receive information does not waste time. What is most important is that the information is already in the hands of everyone, it is on hand phones. Written electronic media as elsewhere in Kosovo have transformed the world into a village where information becomes obsolete within minutes. Nonetheless there have been consistently witnessed sensational titles $\mathrm{i}$ written media in Kosovo are depicted sensational titles, short text within the news, speed of news and the multitude of news published within the day. They have very little or have all the correspondents-reporters removed, and they do not have the first giver of information. Information is provided free of charge by random citizens and is also distributed free of charge. However, along with the data provided by the research, it can be drawn the conclusion that apart from the sensational titles and despite the multiplicity of news stories, the reliability of newspapers published in print media in Kosovo is unsatisfactory. In this point of view the information published in these media is irrelevant and in disregard with the main purpose and the underlying function of information. From the eye of a scholar, electronic print media in Kosovo violate the journalistic codex and violate ethics in journalism. Printed electronic media have gained significant popularity at the expense of the traditional press, because the very nature of their action prompts them to provide quick, responsive, and varied information at no cost. Given the speed of information dissemination, it often happens that they are inaccurate, because written electronic media provide space for freedom of expression, enabling individuals to become creators of content, regardless of the quality and accuracy. This has caused these media to carry an excessive power and violate the privacy and integrity of individuals. 
This is also evidenced by the latest European Commission (EC) report, reiterating that freedom of expression is not well monitored by regulatory authorities, referring to the Independent Media Commission (IMC) and the Press Council of Kosovo (PCK). 


\section{Bibliography}

Alexander, A. [et al.] (2004), Media economics: theory and practice -3rd ed.

Copyright (C) 2004 by Lawrence Erlbaum Associates, Inc

Bergstrom, Bo. Bazat e komunikimit pamor. Tiranë, 2010

Fuga, Artan\& Bashkim Gjergji, Gentiana Skurra, Iris Luarasi, Jonila Godole, Media në demokratizim. Papirus. Tiranë, 2014

Kosumi, Bajram. Zhanret e gazetarisë. UBT. Prishtinë, 2016.

Kovach, Bill\& Tom Rosenstiel. Elemete të gazetarisë. ISHM. Tiranë, 2009

Russ-Mohl, Stephan. Gazetaria. Tiranë, 2010

Selimi, Ferid. Transmetuesi publik. Jehona. Prishtinë, 2016

Kushtetuta e Republikës së Kosovës,

http://citeseerx.ist.psu.edu/viewdoc/download?doi=10.1.1.476.3955\&rep=rep1\&type =pdf Alexander, A [et al.] (2004), Media economics: theory and practice -3rd ed.

Copyright (C 2004 by Laërence Erlbaum Associates, Inc, pg. 21

http://citeseerx.ist.psu.edu/vieëdoc/download?doi=10.1.1.476.3955\&rep=rep 1\&type= pdf Clemons, E\&K. Lang, (2003). The Decoupling of Value Creation from Revenue: A Strategic Analysis of the Markets for Pure Information Goods, Information Technology and Management 4, 259-287, 2003 Kluwer Academic Publishers. Manufactured in The Netherlands.

Gazeta Zyrtare e Republikës së Kosovës. Prishtinë, VITI III .Nr. 24. 1 maj 2008, Ligji nr. 02/L-65 Ligji Civil Kundër shpifjes dhe fyerjes Mark Marku.

https://link.springer.com/content/pdf/10.1023\%2FA\%3A1022958530341.pdf ASK

(2018), 61.3\% e ekonomive familjare në Kosovë kanë qasje në kompjuterë,

Rezultatet e Anketës së Përdorimit të Teknologjisë Informative dhe Komunikimit (TIK), 2017, Agjencia e Statistikave të Kosovës (ASK)

http://ask.rks-gov.net/sq/agjencia-e-statistikave-te-kosoves/add-news/rezultatet-eanketes-se-perdorimit-te-teknologjise-informative-dhe-komunikimit-tik-2017 BE (2017)Mediat digjitale në Kosovë: Në kontroll të baraspeshës mes lirisë së shprehjes dhe reputacionit, Qershor 6, 2017

http://www.digitalrightskosovo.com/sq/mediat-digjitale-ne-kosove-ne-kontroll-tebaraspeshes-mes-lirise-se-shprehjes-dhe-reputacionit/

Telegrafi.com(2013)Gazetat po “vdesin”, ua zënë vendin portalet!, 25.03.2013 https://telegrafi.com/gazetat-po-vdesin-ua-zene-vendin-portalet/

KIPRED\&OSBE (2010), Tirazhi dhe politizimi i mediave të shkruara në Kosovë, Botues Organization for Security and Co-operation in Europe, Data 26 prill 2010 https://www.osce.org/sq/kosovo/67791?do\%C3\%ABnload=true ICERTIAS (2017) "Koha Ditore" vlerësohet si gazeta më e mirë në Kosovë, 19 Janar 2017 https://cms.koha.net/?id=27\&l=152650

Faqja e portalit të gazetës online "Express": https://www.gazetaexpress.com/ Faqja zyrtare e portalit të gazetës online "Express" në rrjetin social facebook https://www.facebook.com/GazetaExpress/

Faqja e portalit të gazetës online "Koha.net": https://www.koha.net/ Faqja e portalit të gazetës online "Koha.net" në rrjetin social facebook https://www.facebook.com/portalikohanet/ 